論文

\title{
プラスチックスの引張破壊および圧縮破壊に及ぼす 変形速度と環境温度の影響*
}

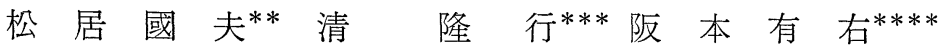 \\ Effects of Strain-Rate and Temperature on Stress-Strain Behavior \\ of Some Solid Polymers
}

by

Kunio Matsui, Takayuki SeI

(Faculty of Engineering, University of Tokushima, Tokushima) and Yūsuke SAKAMOTO

(Osaka Gas Co., Osaka)

The effect of deep freezing on the fracture behaviors of solid polymers has been investigated experimentally as a fundamental study of industrial cryogenic crushing operation.

The mechanical properties of polymethyl methacrylate (PMMA) and polyvinyl chloride (PVC) are found to be critically dependent on the temperature $\left(-180 \sim+120^{\circ} \mathrm{C}\right)$ at which they are deformed, as shown by the following equations (1) (3), but are independent of the strain-rate at which they are deformed, in the range of crosshead speed about 0.5 to $500 \mathrm{~mm} / \mathrm{min}$. The values of true breaking stress $\sigma_{B c}$, and breaking strain $\varepsilon_{B c}$ at the ductile-brittle fracture transition temperature $T_{c}$ are the material-constants.

$$
\begin{aligned}
& \sigma_{B} / \sigma_{B c}=\left\{1-e^{-\left(T_{c} / T\right)^{2}}\right\} /\left(1-e^{-1}\right) \\
& \varepsilon_{B c} / \varepsilon_{B}=\left\{1-e^{-\left(T_{c} / T\right)^{3}}\right\} /\left(1-e^{-1}\right) \\
& \varepsilon_{y}=\varepsilon_{B 0}=\left(1-e^{-1}\right) \cdot \varepsilon_{B c}=0.6321 \varepsilon_{B c}
\end{aligned}
$$

\section{1 緒言}

筆者らは, 前報で変形速度 $4.0 \mathrm{~mm} / \mathrm{min}$ 一定の下， 異る環境温度に括ける, プラスチックス材料の応力, ひずみ曲線ならびに破壊挙動についての実験結果を報 告した. 本報では $0.5,4,5,20,50,120,500 \mathrm{~mm} /$ min の異る変形速度の下, $-180 \sim+120^{\circ} \mathrm{C}$ の異る 環 境温度に和ける，プラスチックスの引張応力ーひずみ 曲線, 圧縮応力ーひずみ曲線, 真破壞応力, 破壞ひずみ, 縱弹性係数の变化を調べた実験結果について述べる.

プラスチックスは同一品種のものでも, その成形法, 可塑剤の添加量などによって著しく異る性質を示す. また使用条件，環境条件によってその材料特性が著し く変化する。高温より低温にわたる材料特性の変化に ついては前報でも述べたが，変形速度によってもかな り影響されるとするのが通説である。衝撃圧縮の範囲 に属する，極端に大きい変形速度の影響については別

* 原稿受理 昭和51年10月12日

** 正会員 德島大学工学部 徳島市南常三島町

*** 徳島大学工学部 徳島市南常三島町

**** 大阪瓦斯(株)総合研究所 大阪市此花区酉島町
報で述べることとして, 本報では, 万能材料試験機に よる, クロスヘッド速度変化 $0.5 \sim 500 \mathrm{~mm} / \mathrm{min}$ の範 囲内での実験結果について述べる.

\section{2 実験装置と実験方法}

島津電子計測制御式万能材料試験機 オートグラフ IS 5000 と恒温槽を併用した. 液体窒素またはドライ アイスを低温冷媒として用い, 高温熱源としては電熱

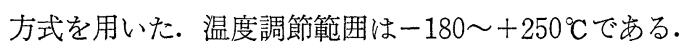
試験片に対する負荷は, サーボモータからクロスーッ ド送りネジを介して機械的に加光る. 試験片の変形速 度が負荷の大小にかかわらず，常に一定であるように サーボ機構で制御を行う。

本報で主として用いた実験試料はポリメチルメタク リレート PMMA である. KYOWA GAS CHEMICAL 製 CAST ACRYLIC SHEET, P-408, 透明, PARAGLAS, KYOWALITE, $2000 \times 1000 \times 8 \mathrm{~mm}$ の 一枚の平板より, ダンベル型引張試験片敊よび柱体圧 縮試験片の両者を，それぞれ負荷方向が一様となるよ らに截り出し, 研摩布で成形仕上げした. 引張試験片 
平行部の最初の長さおよび柱体圧縮試験片の最初の高 さを $l_{0}$ ，断面積をいずれも $f_{0}$ で表した.

実験開始より終了まで, 所定温度に保ち, 液体窒素 気化ガスふん囲気中，またはドライアイス気化ガスふ 几囲気中，あるいは加熱空気らん囲気中のそれぞれに 試験片を曝露した。これら 3 種のふん囲気ガス性質に よる影響の差は，本報実験範囲内では，ほとんど認め られない，そのほかの実験装置と実験方法は前報で述 ベたと特りである。

\section{3 実験結果と考察}

（1）一定変形速度，一定温度に和ける荷重一変形量 曲線をXY レコーダに自動記録する. 一方, 降伏, ネッキング現象出現時および破断時の試料断面積を測 定する．両者より真応力ーひずみ曲線を作図する.

延性破壤よりぜい性破壊への遷移温度 $T_{c}\left({ }^{\circ} \mathrm{K}\right)$ に扝 ける真破壞応力 $\sigma_{B c}\left(\mathrm{~kg} / \mathrm{cm}^{2}\right)$, 破壞ひずみ $\varepsilon_{B c}(一)$ を 用いて，任意温度 $T\left({ }^{\circ} \mathrm{K}\right)$ に括ける真破壊応力 $\sigma_{B}$, 破壞ひずみ $\varepsilon_{B}$ はプラスチックスの材料に無関係に次 式

$$
\begin{aligned}
& \sigma_{B} / \sigma_{B c}=\left\{1-e^{-\left(T_{c} / T\right)^{2}}\right\} /\left(1-e^{-1}\right) \\
& \varepsilon_{B c} / \varepsilon_{B}=\left\{1-e^{-\left(T_{c} / T\right)^{3}}\right\} /\left(1-e^{-1}\right)
\end{aligned}
$$

で表され，また降伏ひずみ $\varepsilon_{y}$ は温度に無関係に次式

$$
\varepsilon_{y}=\varepsilon_{B 0}=\left(1-e^{-1}\right) \cdot \varepsilon_{B c}=0.6321 \varepsilon_{B c}
$$

で表されると前報で仮定した. $\varepsilon_{B 0}$ は $T=0^{\circ} \mathrm{K}$ に括け る破壊ひずみを表す。

$T_{c} / T=0.42,0.45,0.50,0.70,1.0, \infty$ 場合に ついての真応力 $\sigma$ の $\sigma_{B c}$ に対する比 $\sigma / \sigma_{B c}$, 公称応 力 $\sigma_{n}$ の $\sigma_{B c}$ に対する比 $\sigma_{n} / \sigma_{B c}$, ひずみ $\varepsilon$ の $\varepsilon_{B c}$ に 対する比 $\varepsilon / \varepsilon_{B C}$ の関係曲線は，(1) (3) 式を用いれば Fig.1, Fig.2 で表すことができる. 引張りの場合は 前報で示した．引張破壇荷重は低温になるほど増大す る. しかし圧縮破壊荷重は, $T \geqq 2 T_{c}$ の比較的高温領 域では，低温になるほど減少し， $T \leqq T_{\boldsymbol{c}} / 0.70$ の低温 領域では低温になるほど増大する． $T \fallingdotseq T_{c} / 0.60$ 付近

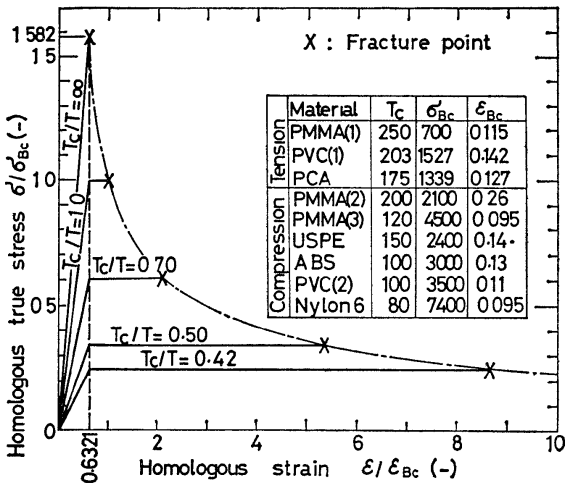

Fig. 1. True tensile stress-strain curves for some solid polymers at several temperature levels.

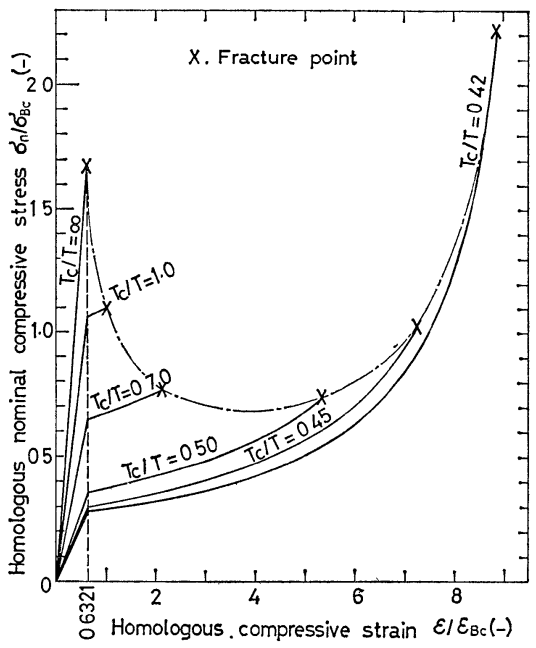

Fig. 2. Nominal compressive stress-strain curves for some solid polymers at several temperature levels.

の温度で最低值をとることが Fig. 2 で認められる. 破壊までの所要仕事量は変形量を考慮して前報で示し たと敊り, 引張り, 圧縮いずれも $T \leqq T_{\boldsymbol{c}} / 1.5$ で最低 値をとる.

(2) 变形速度 $v(\mathrm{~mm} / \mathrm{min})$ と真破壊応力 $\sigma_{B}$ との 関係線図を, 引張りについて Fig. 3 に, 圧縮につい て Fig. 4 に示す. 同一のデータを用いて, 環境温度 $T\left({ }^{\circ} \mathrm{K}\right)$ と真破壊応力との関係線図を Fig. 5 に示す. 当初, 変形速度の増加とともに材料はよりぜい性を示 し，低温にすることと変形速度の増加とはぜい性破壊 に対して同様な効果をもつであろらと期待していた。 Fig. 3 の引張りの場合, この期待に一致する傾向も認 められるが，逆の傾向も認められる.

Fig.4 の圧縮の場合, 比較的高温で真破壞応力が変 形速度の増加とともに減少する傾向が認められる。こ れは, 前掲 Fig. 2 にて, 比較的高温領域では, 公称 圧縮破壞応力が温度低下とともに減少することを示し たが，真応力を示す Fig.4 に拈いても，このことが 影響しているのかもしれない.

Fig. 5 に示すと扣り, 環境温度の変化が真破壞応力

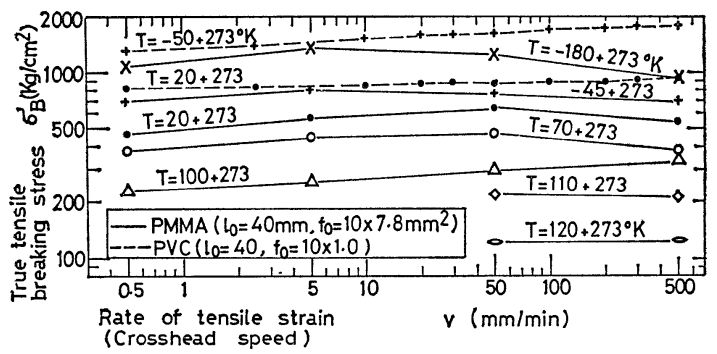

Fig. 3. Dependence of the true tensile breaking stress on the rate of tensile strain. 


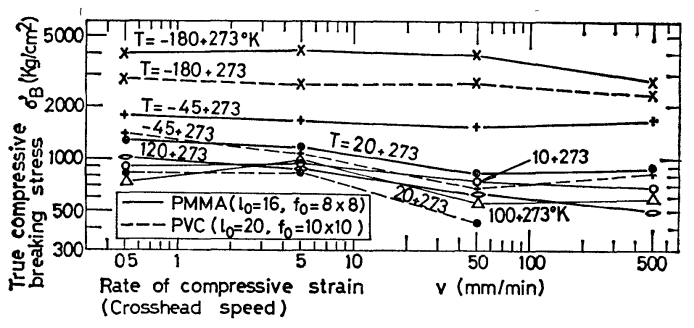

Fig. 4. Dependence of the true compressive breaking stress on the rate of compressive strain.

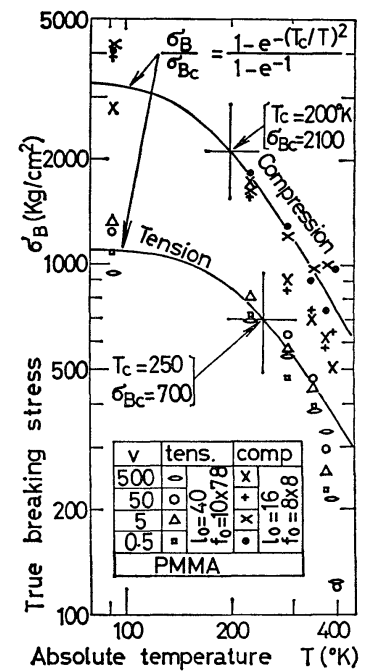

Fig. 5. Relation between true breaking stress and absolute temperature.

に及ぼす影響は著しいるのであり，参考までに(1)式に よる曲線を図中に描いた。Fig. 3〜5 によれば 0.5〜 $500 \mathrm{~mm} / \mathrm{min}$ の実験範囲内では, 速度変化の影響は微 弱である. PMMA の場合, 延性破壞よりぜい性破壞 への遷移温度 $T_{c}$ は，圧縮時に和いて $200^{\circ} \mathrm{K}$ であり， 引張りの場合の $250^{\circ} \mathrm{K}$ よりもより低温に移る. 遷移

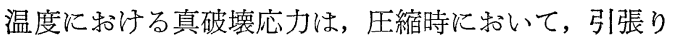
の場合よりも, 著しく大きい値を示す. 眓示の PM-

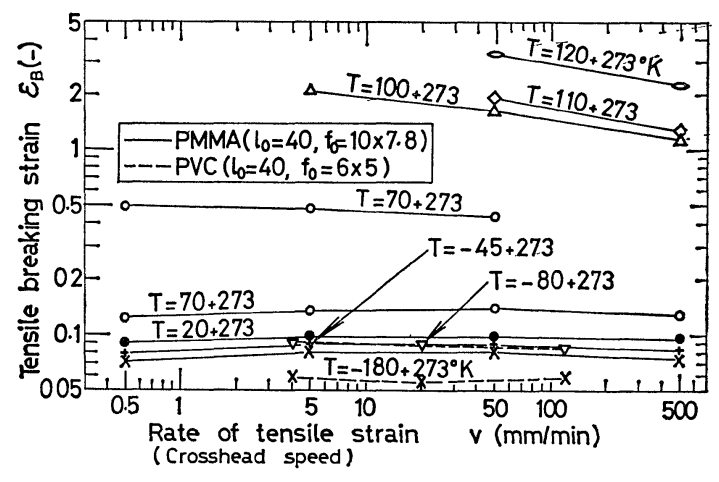

Fig. 6. Tensile breaking strain vs, rate of tensile strain.

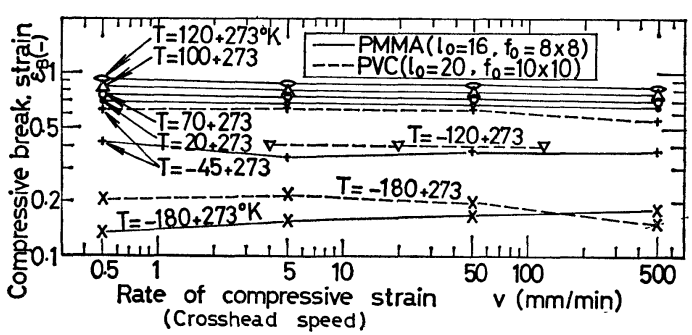

Fig. 7. Compressive breaking strain vs. rate of compressive strain.

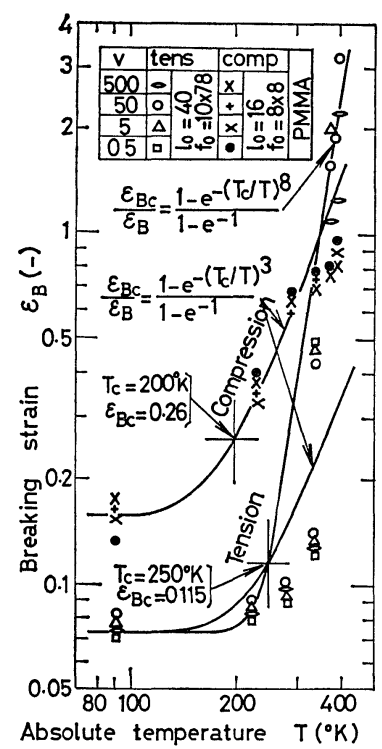

Fig. 8. Breaking strain vs. absolute temperature.

MA では 3 倍であり, 鋳鉄の場合の比に近い。

(3) 变形速度と破壊ひずみ $\varepsilon_{B}$ との関係線図を, 引 張りについて Fig. 6 に, 圧縮について Fig. 7 に示す。 同一のデータを用いて, 環境温度に対する関係線図に 描き直したものをFig. 8 に示す。変形速度の増加と ともに破壞ひずみが減少するであるらとの当初予想に 一致する傾向が認められる場合があるが，それと逆の

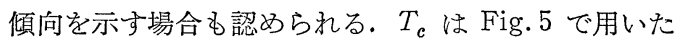
值をとのまま用いている．環境温度の変化が破壤ひず みに及ぼす影響は著しいるのであり，これに比へ，速 度変化の影響は微弱である，参考までに前述の(2)式に よる曲線を Fig. 8 の図中に描いた. 引張りの場合, (2)式中の墨指数を 3 から 8 亿变更したものも描いた.

(4) 引張り, 压縮降伏点に和けるひずみ $\varepsilon_{y}$ は, 変 形速度の $0.5 \sim 500 \mathrm{~mm} / \mathrm{min}$ の変化に注とんど影響 されず, 前述の(3)式が汇涪成立する. 縱弾性係数 $E$ の 変形速度による影響を引張りの場合 Fig. 9 飞, 圧縮 の場合 Fig. 10 に示す. 温度変化のE K及ぼす影響が 著しいのに比べ，速度変化の影響は微弱である。 


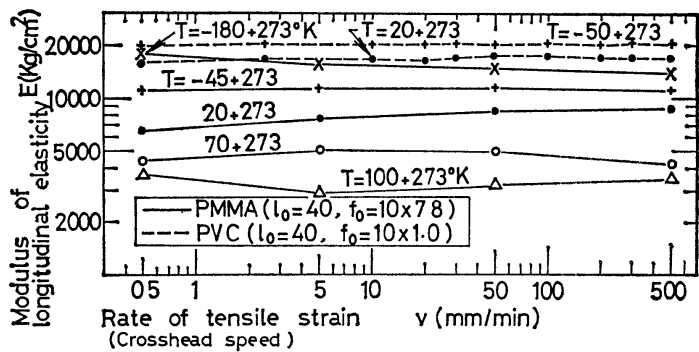

Fig. 9. Modulus of longitudinal elasticity vs, rate of tensile strain.

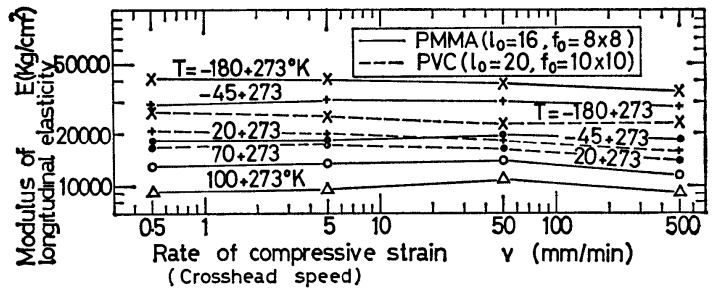

Fig. 10. Modulus of longitudinal elasticity vs. rate of compressive strain.

（5） 最大引張荷重 $P_{\max }(\mathrm{kg})$ 飞対する引張破壞荷 重 $P_{B}(\mathrm{~kg})$ と, $P_{\max }$ に対する破断面積 $f_{B}\left(\mathrm{~cm}^{2}\right)$ との 関係線図を，ポリカーボネート PCA の場合 Fig. 11 にナイロン 6 ，ナイロン66の場合を Fig. 12 に示す. $T_{c} / T \leqq 1.0$ の比較的高温では, 降伏現象, ネッキン グ現象を認め, 荷重一定, 断面積一定, 真応力一定で 破壊にいたり，延性破壊を示す。この場合，次式が成

$$
P_{B} / P_{\max }=P_{B c h} / P_{B c l}=f_{B c h} / f_{B c l}
$$

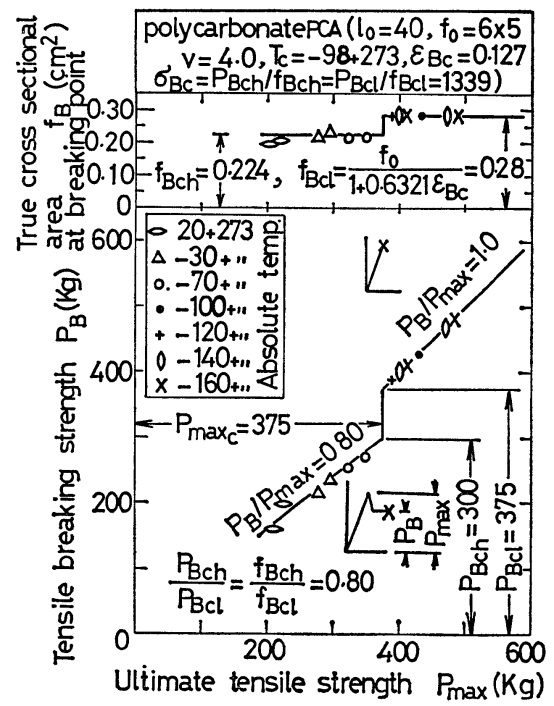

Fig. 11. Comparison between tensile breaking strength or true cross sectional area at breaking point and ultimate tensile strength for the polycarbonate PCA at several temperature levels.

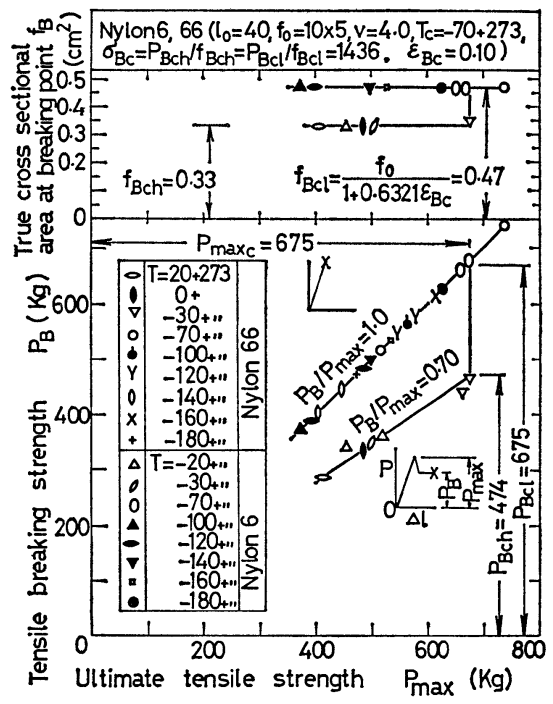

Fig. 12. Tensile breaking strength vs. ultimate tensile strength, true cross sectional area at breaking point $v s$. ultimate tensile strength for the nylon 6, 66 at several temperature levels.

立する. 上式の值が前報の PVC では 0.60, 本報の ナイロン 6 , ナイロン 66 では $0.70, \mathrm{PCA}$ では 0.8 である. 材料特有の值であると考学る。

延性・や゙い性破壊の遷移温度 $T_{\mathrm{c}}$ は前の 3 者では一 $70+273^{\circ} \mathrm{K}, \mathrm{PCA}$ では $-98+273^{\circ} \mathrm{K}$ であり, 遷移温 度飞敊ける真破壞応力 $\sigma_{B c}=P_{B c h} / f_{B c h}=P_{B c l} / f_{B c l}$ は 材料特有の值を示す.

$T_{c} / T \leqq 1.0$ の延性破壞範囲では, 低温になるほど, 真破壞応力の值は(1)式に従って増大する.

$T_{c} / T>1.0$ のぜい性破壞範囲では，低温になる注 ぞ, 真破壊応力の值が(1)式に従って增大する場合が多 いことを前報で示した。しかし本報のナイロン 6,66 では, 引張破壊荷重, 真破壊応力いずれも, 低温にて 著しく減少する場合があることが認められる．このよ らな場合，(1)式は適用しがたい.Fig. 12 は $v=4 \mathrm{~mm} /$ min 一定の場合の実験結果である. 環境温度, 変形速 度の両者以外の原因で，真破壊応力が変化したもので あろら，低温で破壊荷重が(1)式で表す値よりさらに減 少する場合があることは, 低温粉砕の有利性が前報で 述べた場合よりもさらに著しい場合があることを示し ている.

\section{4 結言}

（1）変形速度 $0.5 \sim 500 \mathrm{~mm} / \mathrm{min}$, 環境温度 - 180 $+120{ }^{\circ} \mathrm{C}$ 実験範囲内では, 変形速度の変化はPMMA, PVC の引張り, 西るいは圧縮真破壞応力, 破壞ひず み, 縱弾性係数, 降伏ひずみのいずれにる, 泀とんど 影響を及ぼさない。

環境温度の変化は, 真破壞応力, 破壞ひずみ, 縱弾 
性係数のいずれにも著しい影響を及ぼす，(1)，(2)式を 適用して差支员ない場合がある. しかし遷移温度以下 の低温ぜい性破壞範囲ではナイロン 6，66 の場合， 破壊応力が著しく減少して(1)式を適用することができ ない。

（2）延性破壊よりぜい性破壊への遷移温度およびこ の温度に和社る真破壊応力，破壊ひずみは材料による 定数であり, 同一材料でる, 引張りと圧縮とでは著し く異る值をとる場合がある.

最後に，実験装置の一部を貸与していただいた大阪 瓦斯株式会社総合研究所所長，ご協力をいただいた同
社 LNG 班, 当時卒業研究学生礎良博, 三木寿夫, 林 輝, 村尾久司, 小西博, 丸子修, 佐伯敏雄, 山田康夫, 幸久良, 宮本敏治, 森保久, 田中良治, 隣良平, 松岡 義孝の皆さんに和礼申し上げて結びとする.

(昭和 48 年10月15日 化学工学協会第 7 回秋季大会にて講演)

1）松居國夫, 清 隆行, 礎 良博, 岡田信彦, 材料, 24, 1057 (1975).

2) 松居國夫, 礎 良博, 清 隆行, 中井利明, 材料, 26, 779 (1977). 